
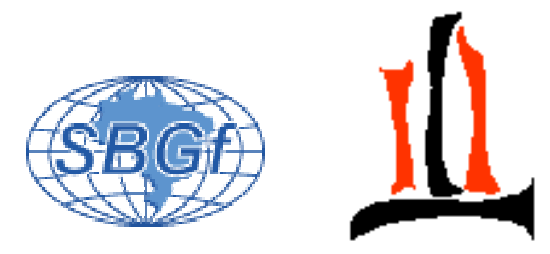

São Paulo 2004

\title{
Basement Depth in the Paraná Basin from Joint Inversion of Teleseismic Receiver Functions and Magnetotelluric Sounding
}

\author{
Ivan Zevallos, Marcelo Assumpção (IAG-USP, São Paulo, ivan@iag.usp.br; marcelo@iag.usp.br), and \\ Antonio L. Padilha (DGE-INPE, padilha@dge.inpe.br)
}

Copyright 2004, SBGf - Sociedade Brasileira de Geofísica

Este texto foi preparado para a apresentação no I Simpósio Regional da Sociedade Brasileira de Geofísica, São Paulo, 26-28 de setembro de 2004. Seu conteúdo fo revisado pela Comissão Tecno-científica do I SR-SBGf mas não necessariamente representa a opinião da SBGf ou de seus associados. E proibida a reprodução total ou parcial deste material para propósitos comerciais sem prévia autorização da SBGf.

\begin{abstract}
Flood basalts in the Paraná basin make exploration of the deeper sedimentary sequence more difficult with seismic reflection methods. We present a new method to obtain information about sub-basalt layers by joint inversion of Receiver Functions (RF) and Magnetotelluric (MT) data. Using genetic algorithm, we obtain 1D models of the main layers of the basin beneath three seismographic stations. Thicknesses of the basalt layer were estimated at $1 \mathrm{~km}$, and basement depth were found to range from 3.7 to 4.4 $\mathrm{km}$, roughly consistent with expected values based on the sparse regional borehole data. Joint inversion produces more stable models than inversion of RF or MT data alone. Deep earthquakes in the nearby Nazca plate subduction zone are a good source of high frequency $\mathrm{P}$ waves making the joint RF+MT inversion a promising method to study shallow sedimentary basins in Brazil.
\end{abstract}

\section{Introduction}

Imaging sub-basalt layers by conventional seismic reflection methods can be a difficult problem in many areas. Seismic surveys in the Paraná basin in the 1980's could not always find the crystalline basement very clearly (Rosa et al., 1982; Souza, 1982). The high seismic velocity of the flood basalts create a major obstacle to image the underlying sedimentary structures with lower seismic velocity (e.g., Moritz \& White, 2001). The large acoustic impedance contrast (reflectivity coefficient) between the shallow weathered basalts and fresh volcanic rocks and between this and the sedimentary layers, rebound and scatter much of the incident seismic energy. Multiple reflections in the basalt layer often obscure the weak signals from the deeper interfaces, and interference from interbedded units within the basalt act as a low-pass filter to the seismic waves (Souza, 1982; Ziolkowski and Fokkema, 1986). For these reasons, magnetotelluric soundings were used for a regional mapping of basement depths in the Paraná basin (Stanley et al., 1985). Some alternatives have been proposed to improve the seismic response from basalt-covered areas, such as wide-angle data (Jarchow et al., 1994) and low-frequency reflection data (Souza, 1982; Ziolkowski et al., 2003). In our study we analyse data from distant earthquakes together with magnetotelluric soundings to investigate the main layers of the basalt covered intracratonic Paraná basin and determine the basement depth.

Seismological methods have been extensively developed to extract information about the receiver structure beneath a seismic station from the records of distant earthquakes, called Receiver Function (RF) method (e.g., Langston, 1979; Ammon, 1991; Wilson \& Aster, 2003), and have been successfully used for deep crustal studies worldwide (e.g., Zandt \& Ammon, 1995). Crustal studies in the Paraná basin using RF (Assumpção et al., 2002; França \& Assumpção, 2003) show a series of shallow reverberations and conversions due to the sedimentary pack beneath the station. For deep crustal studies with $\mathrm{RF}$, frequencies lower than $\sim 1 \mathrm{~Hz}$ are commonly used. Much higher frequencies can be used to study shallow layers. The Paraná basin is conveniently located near the Nazca plate subduction zone, where the high frequency $P$ waves from intermediate and deep earthquakes are not much attenuated since the propagation path avoids the asthenospheric wedge above the subduction zone, and the asthenosphere beneath the South American stable platform is not much developed.

\section{Geology}

The study area (Fig. 1) is characterized mainly by basalt rocks (Serra Geral formation of Late Jurassic age), with a thin cover of sandstones (Adamantina formation of the Cretaceous Bauru group). Basalt thickness is expected to be around $1 \mathrm{~km}$ beneath our seismic stations. Below the basalt layer, sandstones of the Paleozoic Botucatu Formation holds the important Guarany acquifer. The dashed lines in Fig. $1 \mathrm{~b}$ are interpolated values of basement depth, based on very sparsely distributed borehole data, where a value of the order of 4 to $5 \mathrm{~km}$ is expected. Stanley et al. (1985) inverted MT soundings with $1 \mathrm{D}$ models and estimated a depth to the electric basement of about $4 \mathrm{~km}$ in this area.

\section{Receiver Function}

The recorded seismic waveform of a distant earthquake has information about the source, path through the mantle and local structure under the station. The deconvolution operation (dividing the radial by the vertical component) removes almost all effects from the source and propagation path in the mantle. The time-domain trace of this transfer function, called the "receiver function" (RF for short), contains essentially all the P- to S-wave conversions and reverberations at interfaces with S-wave velocity contrasts (Langston, 1979; Ammon, 1991; Wilson \& Aster, 2003). Fig. 2 shows the ray diagram for the converted Ps and the multiple phases from one 


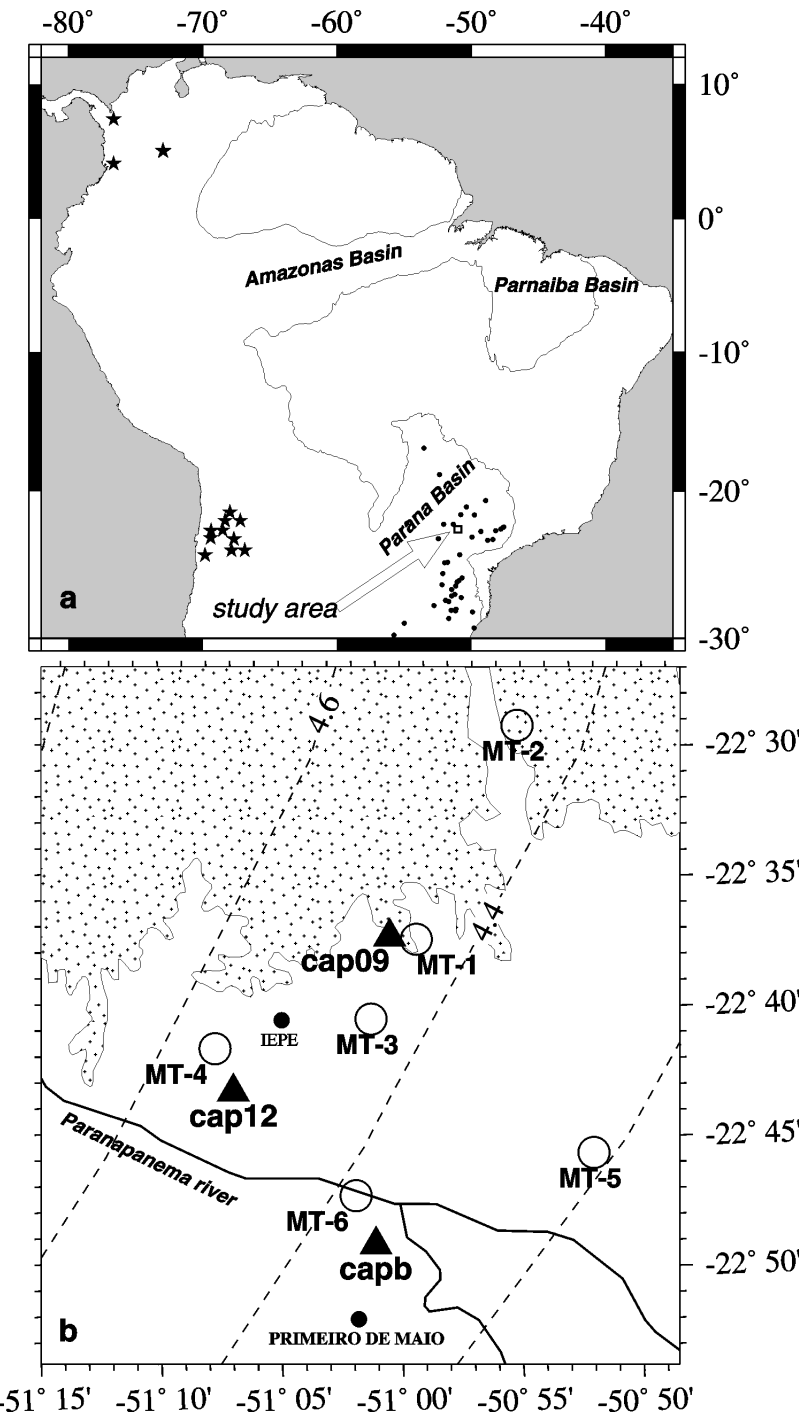

Fig. 1. a) Epicenters (stars) used for the RFs. Dots in the Paraná basin are deep wells that reached the basement. b) Study area with seismic stations (solid triangles) and MT soundings (circles); dashed line is inferred basement depth from the deep weels

interface (bottom of layer 1 ) and the theoretical receiver function. The Ps conversion (labelled "1-s", where the first number refers to the interface) is followed by two multiply reflected phases (labelled here "1-2ps" and "1-p2s", according to the number of branches above the interface, i.e., two P-wave branches or two S-wave branches, respectively). RFs have been successfully used to study crustal and upper mantle discontinuities (e.g., Meijde et al., 2003; Wilson \& Aster, 2003). The near surface lowvelocity layers in a sedimentary basin affect the shape of the receiver functions but are usually modelled as a single average layer in studies of the deep crust (e.g., Assumpção et al., 2002; Meijde et al., 2003). Detailed information of the sedimentary layers, such as obtained by Julià et. al.(2004), are rarely a target for receiver function analysis. This is because the high frequencies necessary to sample thin layers are more susceptible to scattering from small scale lateral structure variations, and the usually low signal-to-noise ratio at frequencies above $\sim 4 \mathrm{~Hz}$ for teleseismic distances.
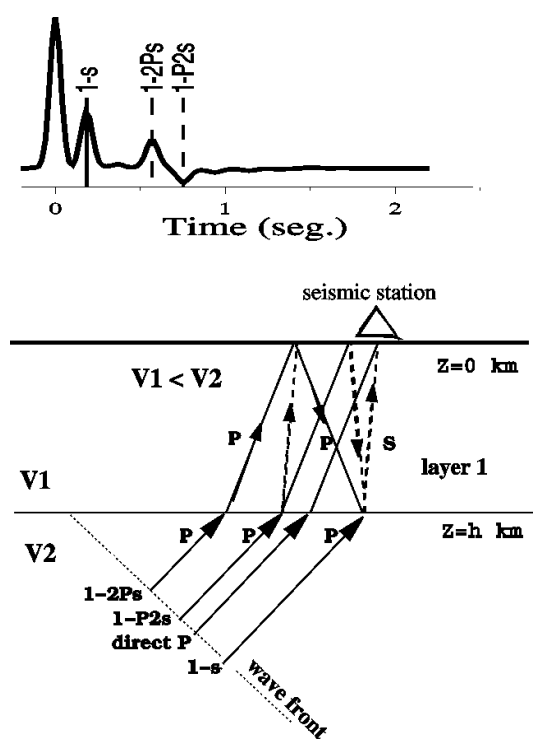

Fig. 2. Simplified diagram showing the various P-to-S converted waves from a single interface. top) receiver function. bottom) raypaths. Note that the phase 1-p2s is actually composed of two different phases with the same arrival time for horizontal layers: 1 -pss + 1-sps.

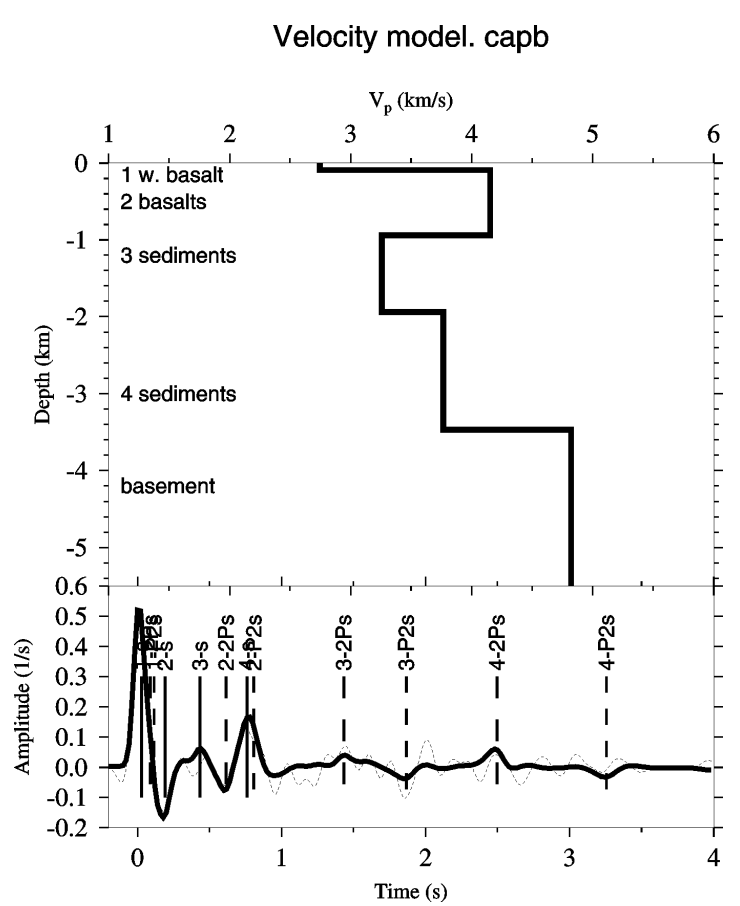

Fig. 3. RF for four layers over a half-space. Velocity model taken from the inversion results of station capb. The first number in the phase labels refers to the bottom of the layer at which conversion and reflections will occur. For example, "2-s" is the P-to-S conversion at the bottom of layer 2; phase "3-2ps" is the $P$ incident at the bottom of layer 3 , followed by two branches of $P$ wave and one branch of $S$ wave. 
Fig. 3 shows the expected receiver function from a sedimentary pack consisting of two (weathered and fresh) basalt layers overlying two sedimentary layers. Each interface, such as interface 2 (basalt/sediment) and interface 4 (sediment/basement) will produce three converted phases, one direct P-to-S conversion and two multiply reflected phases. Note that only phases arriving at the station as $S$ waves will show up in the receiver function, as all other reverberations which arrive as $P$ wave will have the same radial/vertical amplitude ratio of the direct $P$ wave and will end up in the first peak of the receiver function after the deconvolution process (Langston, 1979).

We used mainly intermediate depth earthquakes because of their high frequency content, necessary to sample details within the sedimentary basin. Fig. 1a shows the epicenters of the two groups of earthquakes used in this study. The closer events, near the ChileArgentina border at about $20^{\circ}$ distance, range in magnitude from 4.7 to $6.0 \mathrm{mb}_{\mathrm{b}}$ and have hypocentral depths from 50 to $190 \mathrm{~km}$. The other group of events in Colombia, at a larger distance of about $40^{\circ}$, have magnitudes ranging from 5.3 to 6.6 and depths from 8 to $174 \mathrm{~km}$, with the smaller events $\left(m_{b}<5.5\right)$ deeper than $100 \mathrm{~km}$. The shape of the receiver function (i.e, the times and amplitudes of the Ps conversions and multiples) depends on the angle of incidence of the $\mathrm{P}$-wave at the base of the receiver struc-ture, which is determined by the slowness of the $P$ arrival. The similar distances (and P-wave slownesses) within each earthquake group allows to stack the receiver functions to improve the signal-to-noise ratio. To obtain the receiver function, we used the first $20 \mathrm{~s}$ of the $\mathrm{P}$-wave train, although only the first $4 \mathrm{~s}$ of the receiver functions were actually used in the inversion. In deconvolving the vertical from the radial component multiple taper spectral analysis (Park \& Levin, 2000) were used, which minimizes spectral leakage, a common problem in short-length time series. Frequencies up to $10 \mathrm{~Hz}$ were used and spectral estimates of the noise before the P-wave onset was used as the water level to stabilize the deconvolution.

\section{Stacked Receiver Functions}

Fig. 4 shows the receiver functions of station cap09 from the two earthquake groups: Chile-Argentina border with back-azimuths to the West, and Colombia with backazimuths to the NW). High coherence can be observed among the traces with one main peak at 0.9s. The stacked traces were obtained by using the pre-event $r m s$ noise to weigh each individual trace. The stacked trace is shown with a gray band indicating the standard deviation of each stacked sample. The average of all standard deviations was later used in the inversion procedure. The stacked trace indicates there are at least two other smaller peaks at about 0.3 and $0.5 \mathrm{~s}$. Fig. 5 compares the stacked traces for all three stations. Good coeherence is observed among the three stations with two small peaks at about 0.3 and $0.5 \mathrm{~s}$ at all stations and a large peak at $0.75 \mathrm{~s}$ at capb and $0.9 \mathrm{~s}$ at the other two stations. This indicates that the structure of the sedimentary pack is relatively uniform beneath the three stations. cap09

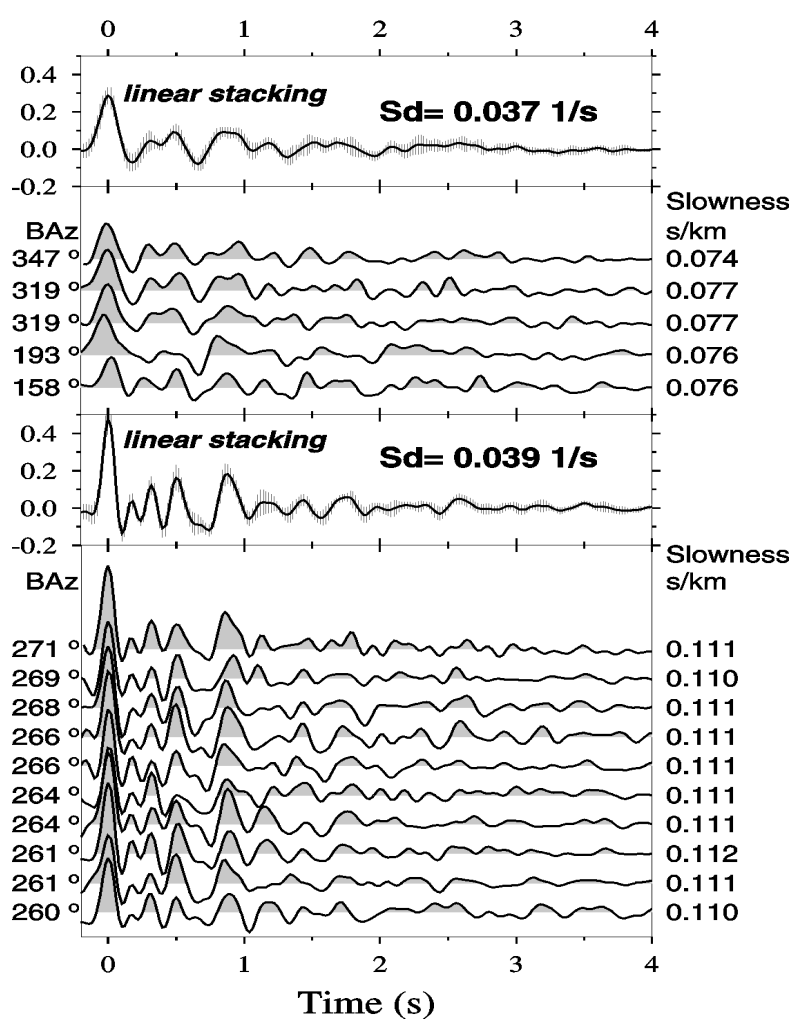

Fig. 4. Receiver function stacks for station cap09 using preevent rms noise as weights. Two groups of individual traces are shown, one for events from the West (bottom section, with slowness around $0.111 \mathrm{~s} / \mathrm{km}$ ), and the other for events from NW (top section, with slownesses around $0.077 \mathrm{~s} / \mathrm{km}$ ). Gray zone around the stacked trace denotes the standard deviation.

\section{3 stations RF stacks}

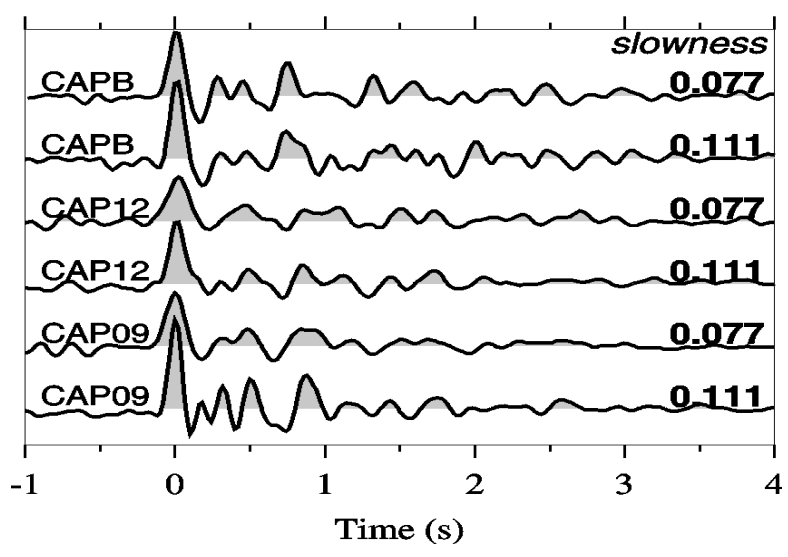

Fig. 5. Comparison of the RF stacks for the three stations. Numbers on the right are the average slowness of each stack. Note the large peak at 0.75 s for capb and 0.9 s for cap12 and cap09, which is the P-to-S conversion at the sediment/basement interface. 


\section{Magneto-Telluric soundings}

The magnetotelluric (MT) method measures the naturally occurring electromagnetic fields to determine sub-surface resistivities. The source signals are caused by magnetospheric and ionospheric currents (period above $1 \mathrm{~s}$ ) or by lightning discharges on a near global scale (periods lower than $1 \mathrm{~s}$ ). The depth to which the incident electromagnetic fields penetrate depends on the period of the field and the resitivity of the medium. By studying the variation in response as a function of period the variation in resistivity as a function of depth may be determined.

The fundamental quantity of interest for MT is the impendance tensor $\mathbf{Z}$ which is the transfer function between mutually orthogonal, horizontal components of magnetic and electric fields,

$$
\begin{aligned}
& E x=Z x x H x+Z x y H y \\
& E y=Z y x H x+Z y y H y
\end{aligned}
$$

where $\mathrm{E}$ and $\mathrm{H}$ are horizontal components of the electric and magnetic fields, respectively, and $(x, y)$ denotes the orthogonal components of horizontal direction.

For a one-dimensional (1D) horizontally-layered conductivity structure (as, for instance, in a sedimentary basin), the impedance tensor takes on a very simple form,

$$
Z x y=E x / H y=-Z y x=-E y / H x ; \quad Z x x=Z y y=0
$$

The MT response is commonly expressed through the magnitude (apparent resistivity) and phase of the impedance tensor components. Plots of apparent resistivity and phase against frequency are the results of a MT sounding at a given site. A fuller description of the MT method is given by Vozoff (1991).

In this study, MT data were collected at six different sites (Fig. 1b), one site near each of the seismic stations and the others more distant to allow for remote reference processing. Commercial wide-band MT systems (ADU 06 from Metronix) were used at every site in a coordinate system with one of the horizontal axis aligned with the magnetic meridian. The telluric field variations were measured with $100 \mathrm{~m}$ dipoles, in a cross-configuration, with non-polarizable lead-lead chloride electrodes, whereas the magnetic fields were measured with induction coils for the two horizontal and one vertical components.

The complex-valued MT tensor elements were estimated using the code from Egbert and Booker (1986). As the raw data had excellent quality, processing with remote reference was not necessary. Fig. 6 shows the apparent resistivity and phase curves for some sites after single station processing. The shape of the curves are typical of a sedimentary basin. The increase of the apparent resistivities up to about $0.1 \mathrm{~s}$ results from the increased resistivities of the fresh basalt layer. The low values between 1 and 10s are caused by the low resisti- vities of the sedimentary layers, and the final increase at longer periods results from the high resistivities of the basement. The similarity of apparent resistivities and phases calculated from the $X Y$ and $Y X$ components of the impedance tensor shows that the geoelectrical structure can be well explained with 1D models. Different tests of the impedance tensor confirmed the 1D nature of the sedimentary pack. Apparent resistivities and phases can then be inverted to an assumed 1D layered structure under each site. Rotationally invariant data (Ranganayaki, 1984) have been used, as they proved usefull in reducing the effects of local structures (Ingham, 1997).

\section{MT single station processing}

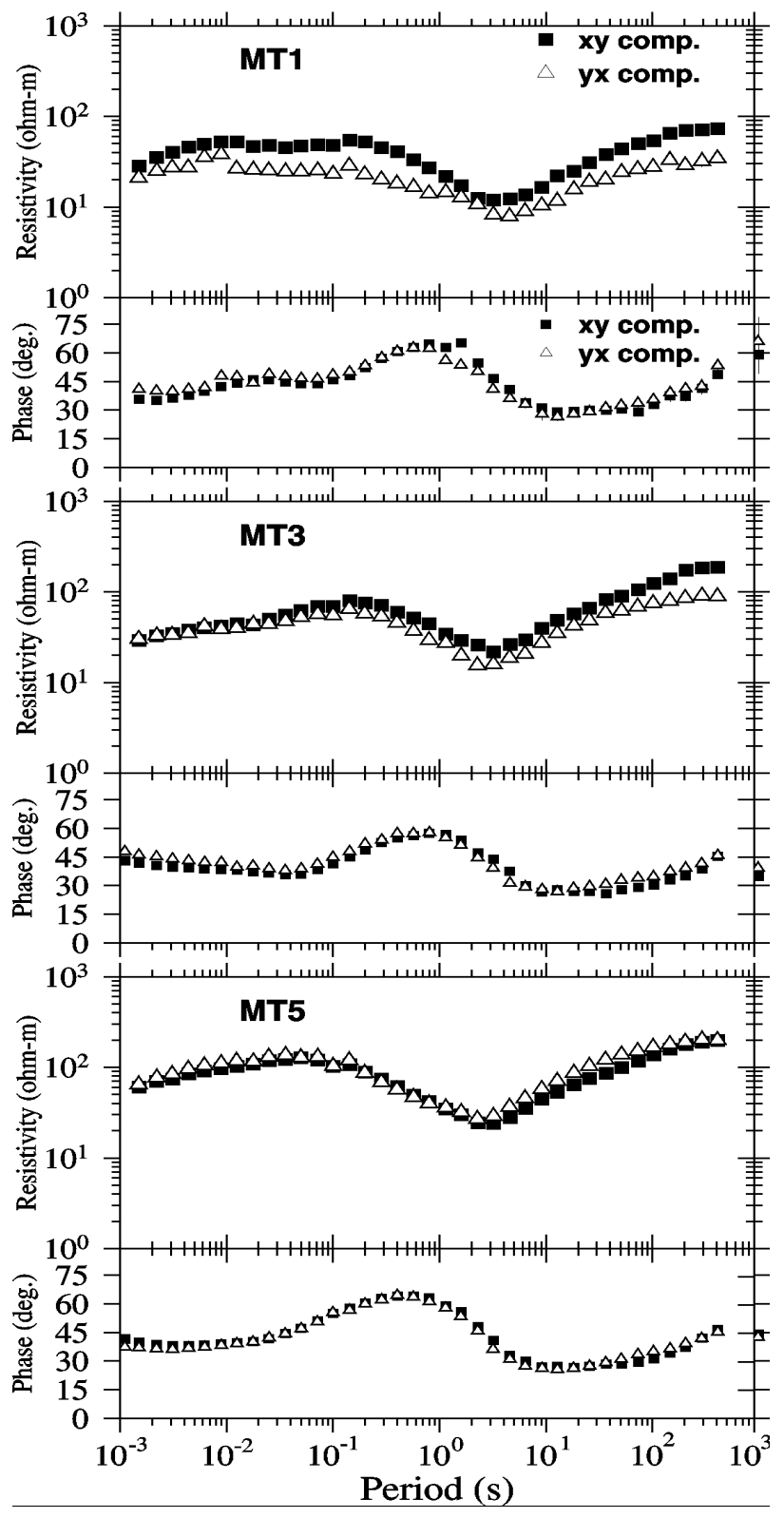

Fig. 6. Examples of apparent resistivities and phases for three of the six MT soundings. Note good coherence between XY and YX components indicative of 1D structure. 


\section{Joint inversion with Genetic Algorithm}

Modelling the receiver function waveform is a highly non-unique problem (e.g., Ammon et al., 1990) because any specific peak can be interpreted in different ways, such as a $P$ to $S$ conversion from a deep interface or a multiply reflected phase from a shallower layer. Linearization methods can be used to model RF (Ammon et al., 1990; Ammon, 1991) using several different starting models to account for the non-uniqueness. Regularization is often necessary, such as smoothness constraints, to stabilize the solutions. Alternatively, global search methods like Genetic Algorithm (e.g., Shibutani et al., 1996) can also be used to account for the solution diversity.

To invert RF and MT data simultaneously, we used a Genetic Algorithm (GA) procedure with the subroutines of Levine (1996). GA is useful for allowing the range of model parameters to be chosen according to a-priori geological information. We modeled the sedimentary basin with four layers over a half-space: the first two layers represent weathered and fresh basalt, the third and fourth layers are sedimentary rocks, and the half-space is the granitic/gneissic basement. $\mathrm{Vp} / \mathrm{Vs}$ ratio was fixed for all layers at 1.76 based on analysis of local induced seismicity by Assumpção et al. (1995). Souza (1982) estimated $\mathrm{Vp} / \mathrm{Vs}$ ratios of about 1.9 for the basalt and 1.7 for the underlying sediments, which would give an average value for the four layers close to the adopted 1.76. The limits for the P-wave velocity in the fresh basalt layer were 4.0 to $4.4 \mathrm{~km} / \mathrm{s}$.) MT soundings in the Paraná basin (Stanley et al., 1985) show a range of resistivities from 2 ohm-m near the surface to $500 \mathrm{ohm}-\mathrm{m}$ in basement. The density of each layer was fixed, based on Yamabe et al. (1997), Yamabe (1999) and well-logging data for the Paraná basin (e.g., Milani et al., 1994).

Some additional geological constraints were imposed to the model. The seismic velocity of the subbasalt layer should be smaller than the velocity of the fresh basalt (allowed Vp range of 3.2 to $3.9 \mathrm{~km} / \mathrm{s}$ ), and the seismic velocity of the basement (half-space) must be larger (range of 4.6 to $6.3 \mathrm{~km} / \mathrm{s}$ ) than that of the overlying sedimentary layer ( 3.9 to $4.5 \mathrm{~km} / \mathrm{s}$ ). All parameters have upper and lower limits according to other regional studies of earth resistivity and seismic velocities in the Paraná basin.

Layer thicknesses were allowed to range from 0.2 to $2.0 \mathrm{~km}$ each, except for the weathered basalt which was restricted to $0.1-0.3 \mathrm{~km}$. Thus, the basement could be as deep as $6.3 \mathrm{~km}$.

\section{Results}

Fig. 7 shows the resulting 20 best models for station capb of the RF+MT joint inversion and the separate inversions with RF and MT data only, together with the data fitting. RF+MT joint inversion produces geologically more reasonable results, such as a $1 \mathrm{~km}$ thick basalt layer, a 3.6-3.8 km depth for the basement and a $\mathrm{Vp}$ of $5.6 \mathrm{~km} / \mathrm{s}$ for the basement.

Similar results were found for the other two stations, cap09 and cap12. Some features are consistently observed at all stations: a shallow surface layer, approximately $100 \mathrm{~m}$ thick, with low velocity and low resistivity. Below, the fresh basalt layer is seen as a high velocity and high resistivity layer. The total basalt thickness was defined at $1.0 \mathrm{~km}$ for all three stations, consistent with expected values in this area of the basin. The velocity inversion zone, seen at about $1 \mathrm{~km}$ depth, coincides with a low resistivity zone corresponding to the sedimentary rocks. The high-velocity half-space has high resistivity confirming it is the crystalline basement.
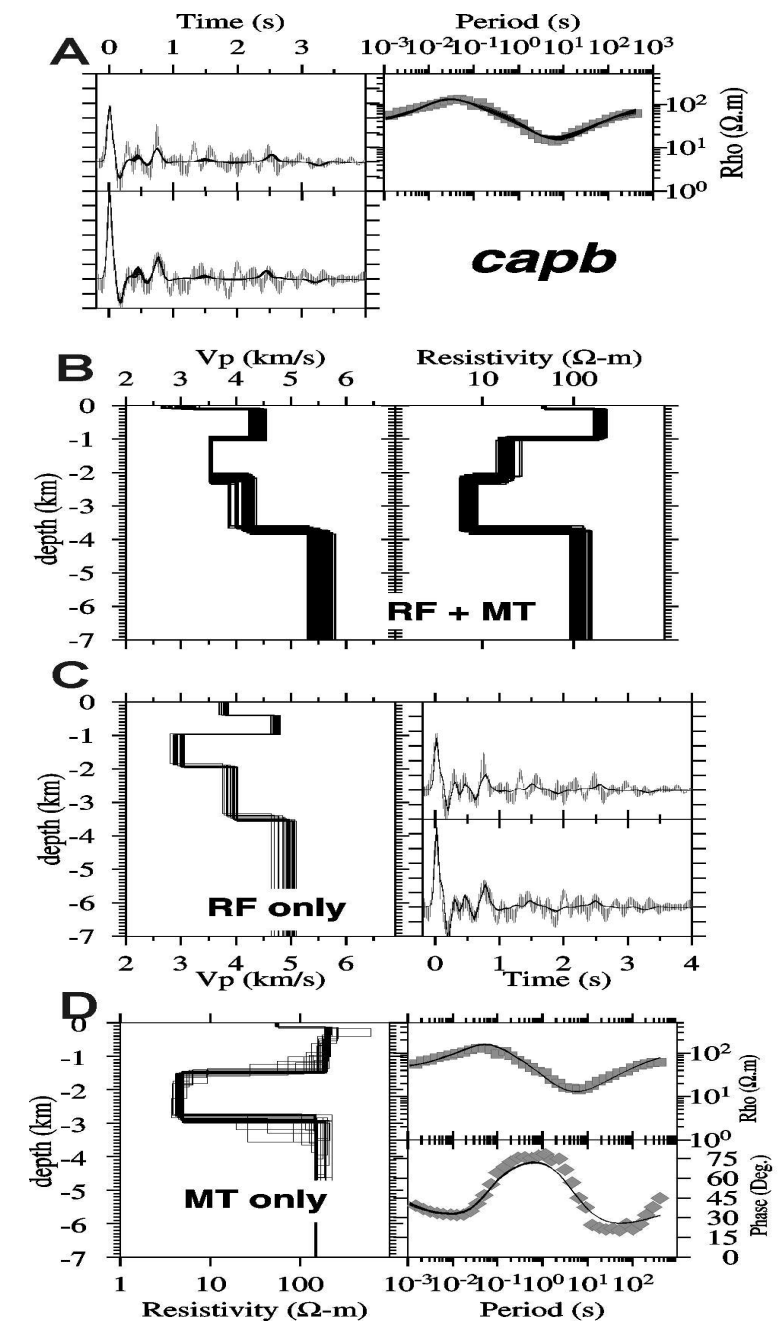

Fig. 7. Inversion results for capb station with velocity models, resistivity models and data fitting. A) RF and resistivity fits for $\mathrm{RF}+\mathrm{MT}$ joint inversion. B) P-wave and resistivity models from the joint inversion. C) Inversion of RF only. D) MT-only inversion. Note that RF-only inversion produces an unrealistic low $\mathrm{Vp}(\sim 5$ $\mathrm{km} / \mathrm{s}$ ) for the basement. MT-only inversion gives a basement depth of only $3 \mathrm{~km}$. Results from the joint RF+MT inversion are geologically more reasonable. 
Receiver functions depend more on velocity contrasts between adjacent layers (which determines the amplitudes of the P-to-S conversions) and vertical travel times (which determines the arrival times of the various phases). For this reason, absolute velocities are not well determined by RF inversion, specially the velocity of the half-space. When inverting for RF only, smoothness constraints were imposed on the velocity model which produced unreallistic low velocities for the basement ( $P$ velocity $<5 \mathrm{~km} / \mathrm{s}$ ). The RF+MT inversion produces more reasonable $V_{P}$ velocities for the basement (a range of $5.0-$ $6.0 \mathrm{~km} / \mathrm{s}$ ) without the need of smoothness constraints to regularize the inversion. Overall, the joint RF+MT inversion produced models geologically more reasonable. The basement depth beneath the three stations varied from $3.7 \mathrm{~km}$ (capb) to $4.4 \mathrm{~km}$ (cap09 and cap12), in general agreement with expected values from regional borehole data.

\section{Conclusions}

High-frequency receiver functions are a promising tool to investigate deep sedimentary basins in Brazil, specially because of the nearby deep earthquakes of the Andean subduction zone. Joint inversion with MT sounding helps to regularize the velocity model and produce more stable results. These preliminary inversion tests show good agreement with the expected main features of the Paraná basin in the Capivara area.

\section{Acknowledgments}

Work supported by a CAPES schollarship, FAPESP (01/ 06066-6) and CNPq. We thank L.C. Ribotta (IPT) for field work and general support of the seismic stations.

\section{References}

Ammon, C., Randall, G. \& Zandt, G, 1990. On the nonuniqueness of receiver function inversions. J. Geophys. Res., 95, 15303-15318.

Ammon, C., 1991. The isolation of receiver effects from teleseismic P waveforms. Bull. Seism. Soc. Am., 81, 2504-2510.

Assumpção, M., Freire, M. \& Ribotta, L.C., 1995. Sismicidade induzida no reservatório de Capivara: resultados preliminares sobre localização de fraturas ativas, IV Int. Congr. SBGf, Rio de Janeiro.

Assumpção, M., D. James \& A. Snoke, 2002. Crustal thicknesses in SE Brazilian shield by receiver function analysis: implications for isostatic compensation. J. Geophys. Res., 107, ESE2-1-ESE2-14, 10.1029/ 2001JB000422.

Egbert, G.D. \& Booker, J.R., 1986. Robust estimation of geomagnetic transfer functions: Geophys. J. R. astr. Soc., 87, 173-194.

França, G. \& M. Assumpção, 2003. Estrutura da crosta em Goiás, usando a função do receptor, e mapa preliminar de espessuras crustais no SE e centro-oeste do Brasil. VIII Congr. da SBGf, Rio de Janeiro, CD-ROM.
Ingham, M., 1997. The use of invariant impedances in magnetotelluric interpretation: Geophys. J., 92, 165-169.

Jarchow, C., Catchings, R. \& Lutter, W., 1994. Large explosive source, wide-recording aperture, seismic profiling on the Columbia Plateau, Washington: Geophysics, 59, 259-271.

Julià, J., Herrmann, R., Ammon, C. \& Akinci, A., 2004. Evaluation of deep sediment velocity structure in the New Madrid zone. Bull. Seism. Soc. Am., 94, 334-340.

Jupp, D.L.B. \& Vozoff, K., 1975. Stable iterative methods for the inversion of geophysical data: Geophys. J. R. astr. Soc., 42, 957976.

Langston, C.A., 1979. Structure under Mount Rainier, Washington, inferred from teleseismic body waves. J. Geophys. Res., 85, 4749-4762.

Meijde, M., Van der Lee, \& Giardini, D., 2003. Crustal structure beneath broad-band seismic stations in the mediterranean region: Geophys. J. Int., 152, 729-739.

Milani, E., França, A. \& Schneider, R., 1994. Bacia do Paraná. Bol. de Geociências da Petrobrás, 8(1), 69-82.

Ranganayaki, R.P., 1984. An interpretive analysis of magnetotelluric data: Geophysics, 49, 1730-1748.

Moritz, M.F. \& White, R.S., 2001. Seismic structure of basalt flows from surface seismic data, borehole measurements, and synthetic seismogram modelling: Geophysics, 66 (6), 1925-1936.

Ranganayaki, R.P., 1984. An interpretive analysis of magnetotelluric data: Geophysics, 49, 1730-1748.

Rosa, A., Tassini, J. \& Backus, M., 1982. Seismic data quality in a basalt covered basin: $62^{\text {th }}$ SEG meeting, expanded abstracts S5.5.

Shibutani, T., Sambridge, M. \& Kennett, B., 1996. Genetic algorithm inversion for receiver functions with ap-plication to crust and uppermost mantle structure beneath Eastern Australia: Geophys. Res. Lett., 23, 1829-1832.

Souza, J., 1982. Transmission of seismic energy through the Brazilian Paraná Basin layered basalt stack: $62^{\text {th }}$ SEG meeting, expanded abstracts S5.6.

Stanley, W., Saad, A.R. \& Ohofugi, W., 1985. Regional magnetotelluric surveys in hydrocarbon exploration, Paraná basin, Brazil. Am. Ass. Petroleum Geol. Bull., 69, 346-360.

Vozoff, K., 1991. The magnetotelluric method, In: E. Nabighian (Ed.), Electromagnetic Methods in Applied Geophysics, SEG, Tulsa, pp. 641-711.

Yamabe, T.H., 1999. Estudos geofísicos para explicar a sismicidade induzida e orientar a exploração de água subterrânea em Nuporanga - SP; PhD thesis, IAG-USP, São Paulo.

Yamabe, T.H., Berrocal, J. \& Diogo, L.A., 1997. Seismic surveys in the Northeastern portion of the Paraná basin: 5th Int. Congr. Braz. Geophys. Soc., CD-ROM.

Ziolkowski, A. \& A. Fokkema, 1986. Tutorial: the progressive attenuation of high-frequency energy in seismic reflection data: Geophys. Prospec., 34, 981-1001.

Ziolkowski, A., Hanssenn, P., Gatliff, R., Jakubowicz, H., Dobson, A., Hampson, G., Li, X. \& Liu, E., 2003. Use of low frequencies for sub-basalt imaging: Geophysical Prospecting, 51, 169-182.

Wilson, D., \& Aster, R., 2003. Imaging crust and upper mantle seismic structure in the southwestern United States using teleseismic receiver functions. The Leading Edge, 22, 232-237.

Zandt, G., \& Ammon, C., 1995. Continental crust composition constrained by measurements of crustal Poisson's ratio. Nature, 374 (9 March 1995), 152-154. 